ZOOLOGIA 30 (4): 363-370, August, 2013

http://dx.doi.org/10.1590/S1984-46702013000400001

\title{
Vocal repertory of Scinax littoreus (Anura: Hylidae) with comments on the advertisement call of the Scinax perpusillus species group
}

\author{
Rafael Pontes ${ }^{1,2}$, Camila Mattedi ${ }^{1} \&$ Délio Baêta ${ }^{1}$ \\ ${ }^{1}$ Universidade Federal do Rio de Janeiro, Museu Nacional. Quinta da Boa Vista, São Cristóvão, 20940-040 Rio de Janeiro, RJ, \\ Brazil. \\ ${ }^{2}$ Corresponding author. E-mail: rafaelcunhapontes@hotmail.com
}

\begin{abstract}
The Scinax perpusillus species group consists of thirteen bromeligenous treefrogs, of which only six have had their acoustic parameters appropriately described. In this work, we present the vocal repertory of Scinax littoreus (Peixoto, 1988) based on recordings obtained from three different populations in the state of Rio de Janeiro, Brazil. Based on our observations we suggest that the vocal repertory of $S$. littoreus is composed of two distinct types of calls. The call named type A, which corresponds to a long series of multipulsed notes, is likely to have a mating function. This type of call is similar to that reported for Scinax arduous Peixoto, 2002, Scinax peixotoi Brasileiro, Haddad, Sawaya \& Martins, 2007, and Scinax perpusillus (Lutz \& Lutz, 1939). However, the type A call of S. littoreus is nonetheless readily distinguishable from the comparable call observed in other congeneric species. The call named type $B$, which exhibits a multipulsed structure, presumably has an aggressive function. We observed that different types of calls could be emitted alone or combined according to the social context. Additionally, we discuss problems involving comparisons of call parameters among species belonging to the S. perpusillus species group, provide an updated geographic distribution map, discuss the conservation status of the included species, and emphasize the importance of acoustic data for the recognition of species groups within Scinax.
\end{abstract}

KEY WORDS. Aggressive call; bioacoustics; bromeligenous; geographic distribution; territorial call.

The Scinax perpusillus species group is composed by bromeligenous treefrogs distributed along the coastal Atlantic Forest and adjacent islands of Brazil, from the state of Espírito Santo south to the state of Santa Catarina. Species of this group also inhabit inland areas of the state of Minas Gerais (Frost 2013, LACERDA et al. 2012). Currently, this group is composed of thirteen species: Scinax alcatraz (Lutz, 1973); Scinax arduous Peixoto, 2002; Scinax atratus (Peixoto, 1988); Scinax belloni Faivovich, Gasparini \& Haddad, 2010; Scinax cosenzai Lacerda, Peixoto \& Feio, 2012; Scinax faivovichi Brasileiro, Oyamaguchi \& Haddad, 2007; Scinax insperatus Silva \& Alves-Silva, 2011; Scinax littoreus (Peixoto, 1988); Scinax melloi (Peixoto, 1988); Scinax peixotoi Brasileiro, Haddad, Sawaya \& Martins, 2007; Scinax perpusillus (Lutz \& Lutz, 1939); Scinax tupinamba Silva \& Alves-Silva, 2008; and Scinax v-signatus (Lutz, 1968).

Scinax littoreus was described based on specimens from the coastal region of the state of Rio de Janeiro, for the municipalities of Maricá (designated as the type-locality), Cabo Frio, and Macaé (Регхото 1988). In the original description, Регхото (1988) characterized the external morphology of adults and tadpoles as well as the osteology of the skull. He did not, however, provide any data on the acoustic repertory of the species. Recently, Alves-Silva \& Silva (2009) studied the behavioral traits of $S$. littoreus, suggesting that the monophyly of the S. perpusillus group is mainly supported by behavioral and morphological traits. Nevertheless, these authors did not provide any information on the advertisement calls of $S$. littoreus and its acoustic parameters.

The use of advertisement calls as a taxonomic tool has been intensified in recent years, culminating with the description of anuran species which are diagnosed based on their acoustic parameters (CANedo \& Pombal 2007, LaCerda et al. 2012, Pombal et al. 2011, TAucce et al. 2012). Despite this progress in the study of acoustic parameters of different anuran groups, to our knowledge only six of the thirteen species belonging to the $S$. perpusillus group have had their advertisement calls appropriately described (Heyer et al. 1990, Brasileiro et al. 2007, Pombal \& Bastos 2003, Peres \& Simon 2011, Lacerda et al. 2012, Silva \& Alves-Silva 2011).

In order to contribute to the knowledge of the acoustic parameters of Scinax perpusillus group, we describe the vocal repertory of $S$. littoreus, compare interpopulational variation of the species' vocal repertory, compare our results with other described calls for $S$. perpusillus group, provide an updated geographic distribution map for $S$. perpusillus, and discuss main problems concerning comparisons of call parameters among species belonging to the $S$. perpusillus species group. 


\section{MATERIAL AND METHODS}

Vocalizations were recorded in situ with a Marantz Portable Recorder PMD222 coupled to a Sennheiser ME66 directional microphone. Whenever possible, the microphone was kept between 1 to $2 \mathrm{~m}$ of a calling male. Advertisement calls were digitalized at a sample rate of $44.100 \mathrm{~Hz}$ and sample size of 16 bits. The temporal parameters were measured directly from the waveform and frequency parameters were measured directly from the audiospectrogram (with window function Hann, amplitude logarithmic, window size 256 samples and overlap 99\%). Sound analyses and graphs were made with Cornell Lab of Ornithology's Raven Pro 1.4 (Bioacoustics Research Program). Air temperature and relative humidity were taken in the field with a digital thermohygrometer Hanna MO800 (to the nearest of $0.1^{\circ} \mathrm{C}$ and $0.1 \%$ of relative air humidity).

Our parameters of interest in this study follow the descriptions of Duellman \& Trueb (1994) and Pombal \& Bastos (2003). We measured the following parameters: 1) call duration (s); 2 ) call interval (s); 3) number of notes; 4) note duration (s); 5) note interval (s); 6) number of pulses per note; 7) interval between the peaks of pulses (s); 8) dominant frequency (Hz); 9) lower frequency recorded $(\mathrm{Hz}) ; 10)$ higher frequency recorded $(\mathrm{Hz})$; 11) frequency modulation; 12) presence of harmonic structure; and 13) shape of the note. Data on quantitative variables are given as minimum - maximum (range \pm standard deviation) and results are given based on interpopulational variation. The populations were discriminated in the tables, and were further compared in the discussion section.

We recorded specimens of Scinax littoreus from three different populations (Fig. 1) as follows: Pedra de Itacoatiara


tion 1), Parque Estadual da Serra da Tiririca, municipality of Niterói, state of Rio de Janeiro, on 31 May 2012 where we obtained 78 calls from six different males. We also recorded 36 calls by two males from Praia do Peró $\left(22^{\circ} 51^{\prime} 18.04\right.$ "S, $41^{\circ} 59^{\prime} 20.81^{\prime \prime W}, 5 \mathrm{~m}$ a.s.l., SAD69) (population 2), in the municipality of Cabo Frio, state of Rio de Janeiro on 10 January 2013. Additionally, 17 calls of one male from a population of S. littoreus at Praia do Forno $\left(22^{\circ} 45^{\prime} 53.09^{\prime \prime} S, 41^{\circ} 52^{\prime} 43.00^{\prime \prime} \mathrm{W}, 16\right.$ $\mathrm{m}$ a.s.l., SAD69) (population 3), in the municipality of Búzios, state of Rio de Janeiro on 6 May 2012.

Additionally, we constructed a distribution map based on the examination of specimens collected in the field, in addition to vouchers deposited in the amphibian collection of the Museu Nacional, Universidade Federal do Rio de Janeiro (MNRJ) and Adolpho Lutz (AL-MN). After analysis, recordings and their vouchers were deposited in the amphibian collection of the Museu Nacional, Universidade Federal do Rio de Janeiro (MNVOC and MNRJ).

Examined specimens. Brazil, Rio de Janeiro: Niterói (Saco do São Francisco: AL-MN 830; Pedra de Itacoatiara: MNRJ
80655-57); Iguaba Grande (MNRJ 60953); Arraial do Cabo (MNRJ 32380-82, MNRJ 32380-82); Cabo Frio (Praia do Peró: MNRJ 47524, MNRJ 84347; Ilha de Cabo Frio: MNRJ 5938997); Búzios (Praia do Forno: MNRJ 82251).

Licenses for scientific activities were issued by Sistema de Autorização e Informação em Biodiversidade, SISBIO; ICMBio (088/2004 and 20385-1) and Instituto Estadual do Ambiente, INEA (002/2010 and013/05, proc. E07/300039/2005).

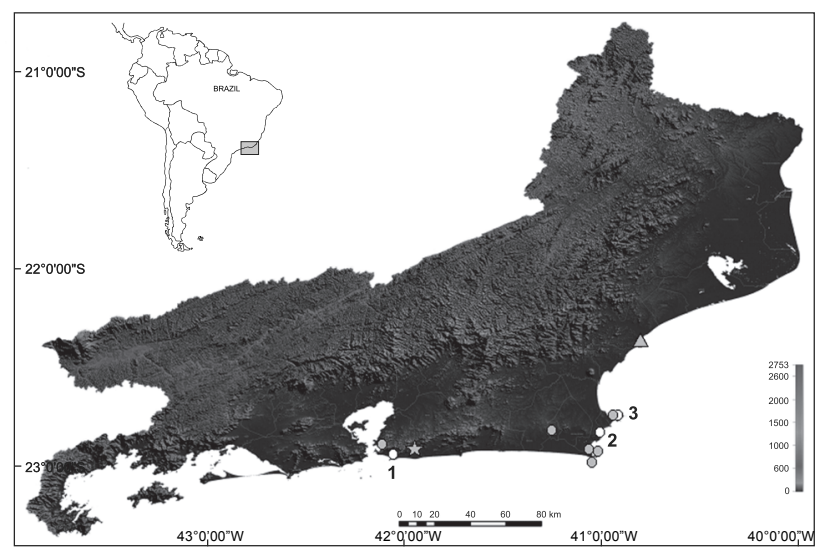

Figure 1. Geographic distribution of Scinax littoreus. ( $\star$ ) Bambui, Municipality of Maricá (type-locality); ( $\odot$ examined specimens; (A) literature record (Регхото 1988); (О) analyzed populations: 1) Pedra de Itacoatiara, Municipality of Niterói; 2) Praia do Peró, Muncipality of Cabo Frio; 3) Praia do Forno, Municipality of Búzios.

\section{RESULTS}

\section{Field observations}

Males from population 1 were recorded calling while perching near the middle section of the external leaves of the tank-bromeliad Alcantarea glaziouana (Leme) J.R. Grant (Fig. 2). All plants were attached to exposed rock surfaces. On average, we observed groups of about 10 calling males near the recorded specimens. Males were distant about 1 to $5 \mathrm{~m}$ from one another. Prior to recording, the registered temperature was $18.0-19.8^{\circ} \mathrm{C}$ and relative air humidity $79.4-82.1 \%$.

Males from population 2 were observed calling from the tips of axillary leaves of the ground tank-bromeliad Neoregelia cruenta (Graham) L.B. Smith on the border of shrubby vegetation in restinga habitat (Fig. 3). We estimated approximately 35 calling males in the nearest 5-8 $\mathrm{m}$, being the closest calling males placed around 1-2 m from recorded males. After recordings, air temperature was registered at $23.1-23.4^{\circ} \mathrm{C}$ and relative air humidity at $89-90.1 \%$.

The specimen recorded from population 3 was on the tip of an external leaf of the tank-bromeliad Neoregelia cruenta. The plant was on flat ground at the border of semideciduous 

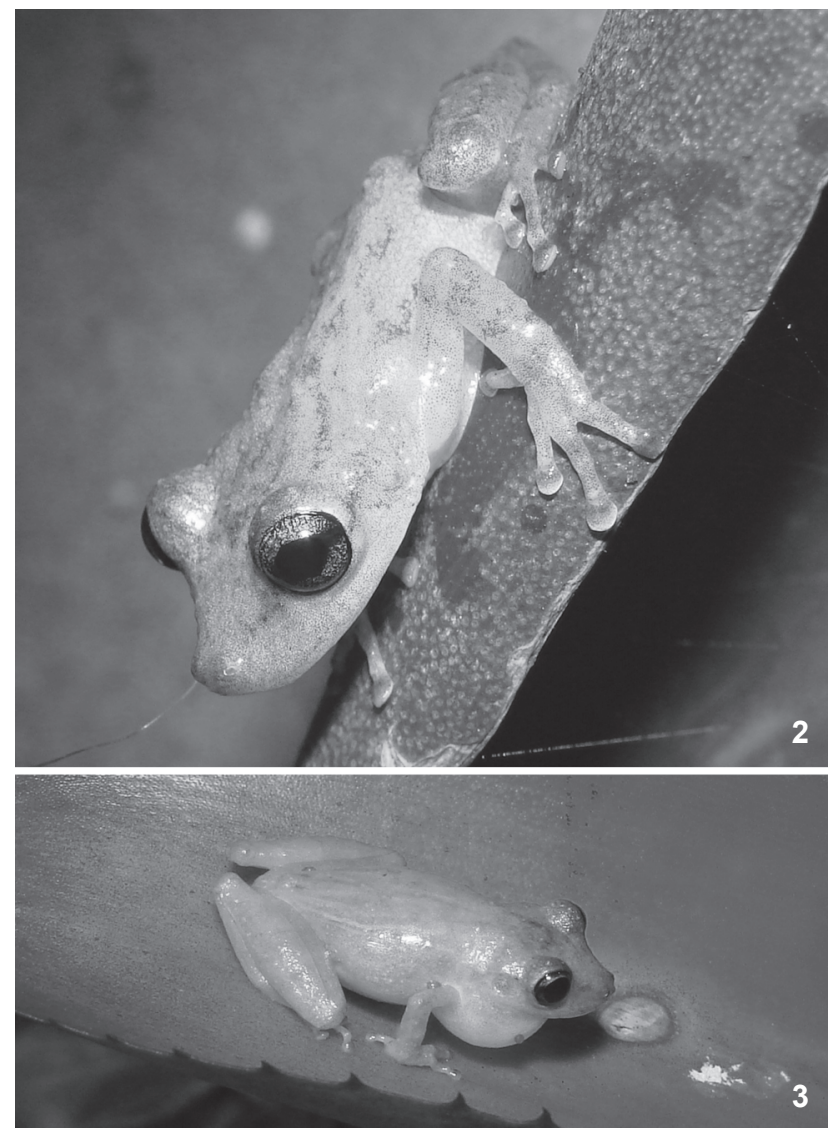

Figures 2-3. Living specimens of Scinax littoreus. Legend: (2) an adult male from Praia do Peró, Municipality of Cabo Frio, RJ (MNRJ 77231) and (3) an adult male from Pedra de Itacoatiara, Parque Estadual da Serra da Tiririca, Municipality of Niterói, RJ (MNRJ 80655). Photos by R. Pontes.

forest. While making recordings, we observed other six males calling in the vicinity (15 $\mathrm{m}$ around) and the closest calling male was $5 \mathrm{~m}$ from the recorded specimen. The registered temperature was $22.9^{\circ} \mathrm{C}$ and relative air humidity was $88 \%$.

\section{Vocal repertory description}

We observed specimens of Scinax littoreus emitting two distinct types of calls, which we named call type A and call type B. Our field observations suggest that call type A corresponds to an advertisement call because this type of call was emitted mainly when fewer calling males where heard. Males emitted type B vocalization when there were higher numbers of calling males in the vicinity. Thus, we suggest that this type of call has either territorial or aggressive functions. The calls were emitted individually with type A 35.6\%, call type B 5.5\%, or combined $58.9 \%$ (Fig. 4). When combined, call type B was emitted immediately after call type A, making call type A shorter than when emitted alone (Figs 5 and 6).
The advertisement call (or call type A) (Figs 7 and 8) of Scinax littoreus lasted from 0.174-0.287 s (0.229 \pm 0.087) with (when emitted alone) the interval between calls varying from $0.980-14.197 \mathrm{~s}(5.981 \pm 2.762)$. It is composed of 2-5 multipulsed notes $(3.6 \pm 0.7)$, each note with $2-9$ pulses $(4.6 \pm 1.3)$ and intervals between pulses peaks ranging from 0.004-0.024 s $(0.009 \pm 0.004)$. The note duration ranged from 0.118 to 0.348 $\mathrm{s}(0.218 \pm 0.07)$ and intervals between notes $0.014-0.038 \mathrm{~s}(0.028$ $\pm 0.006)$. The energy was concentrated in the beginning of the note, which gradually decreased giving an arrow-like shape to the note. The dominant frequency ranged from 4306.6-4651.2 $\mathrm{Hz}(4513.4 \pm 109)$; lower frequency ranged from 2261.2-2756.2 $\mathrm{Hz}(2417.4 \pm 175.76)$ and higher frequency varied from 5892.7 $8122.3 \mathrm{~Hz}(6832.2 \pm 291.29)$. Harmonic bands or frequency modulations were not observed. The repetition rate for calls was $48-67$ calls per minute $(58.4 \pm 19.3)$. The sound produced in this type of call is reminiscent of those produced by a quick and short beat of a rattle.

The elapsed time of territorial or aggressive calls (call type B) (Figs 9 and 10) lasted from 0.220-0.349 s (0.279 \pm 0.087$)$ when emitted alone, while the interval between calls varied from $0.689-1.590 \mathrm{~s}(0.925 \pm 0.199)$. This call type consists of a long series of $8-31$ multipulsed notes $(15.2 \pm 9.1)$; note duration ranged from 0.016 to $0.058 \mathrm{~s}(0.022 \pm 0.011)$. These notes had consistently higher amplitude at the beginning and end of the note. However, intervals between notes varied widely in this type of call, tending to be shorter in the beginning and in the end of the call. In the beginning of the call, intervals between notes ranged between $0.003-0.027 \mathrm{~s}(0.009 \pm 0.004)$ and near the end of the call (i.e., last 5-8 notes), intervals decreased until the notes overlapped (around last 2-4 notes). Each note was composed of $2-4$ pulses ( $3.1 \pm 0.4)$; interval between pulses peaks varying from $0.001-0.004 \mathrm{~s}(0.002 \pm 0.001)$. The dominant frequency varied from 4306.6-4478.9 Hz (4356.2 \pm 87.2$)$; lower frequency ranged from $2152.0-2846.0 \mathrm{~Hz}(2487.5 \pm 182.9)$ and maximum frequency from $5292.0-5839.0 \mathrm{~Hz}(5441.2 \pm$ 119.7); the structure of the call does not suggest the presence of harmonic bands or frequency modulation. To human hearing, this sound resembles the sound produced by the friction of two rough pieces of glass.

\section{Geographic distribution}

According our data, the distribution of Scinax littoreus is strongly associated with coastal and lagoon ecosystems such as restinga formations, lowland ombrophilous forests, and rocky seashores in the state of Rio de Janeiro. On a more local level, this species is associated with tank-bromeliads ( $A$. glaziouana and $N$. cruenta). The southernmost record was at Saco de São Francisco, Municipality of Niterói. North of that, we made recordings from the Municipality of Maricá (typelocality), and Região dos Lagos (Municipalities of Iguaba Grande, Arraial do Cabo, Cabo Frio, and Búzios) to Macaé, the northernmost area of occurrence of this species (Fig. 1), as far as we know. 


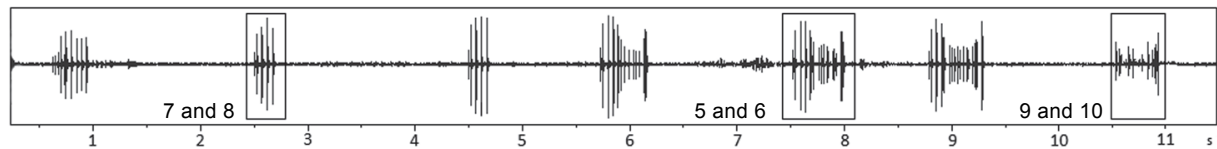

4



5

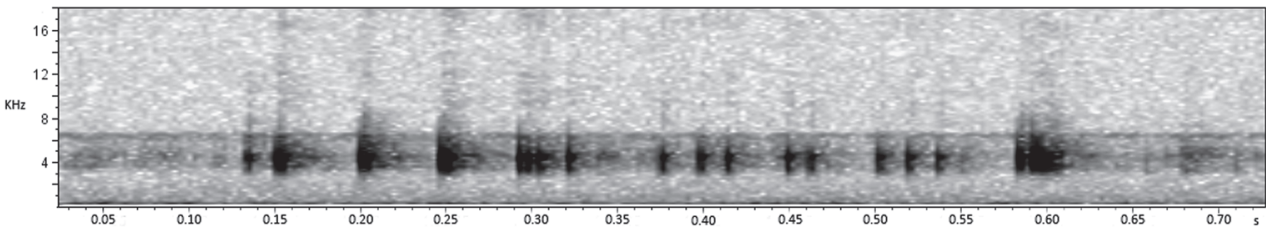

6

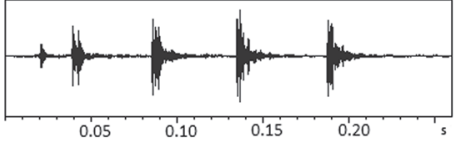

7
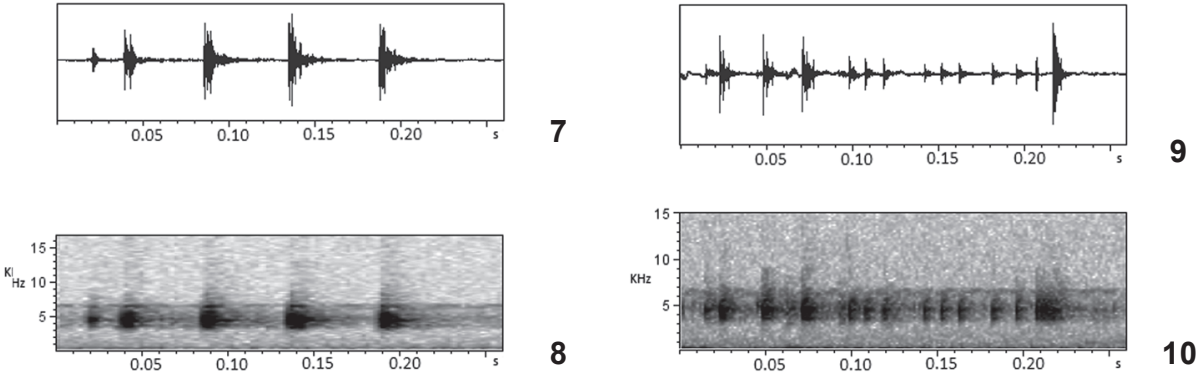

Figures 4-10. Recorded call of Scinax littoreus. Legend: (4) Eleven seconds waveform, squares highlights the different patterns of call emission as follows: (5) Oscilogram and (6) audioespectrogram of combined call type A + B. (7) Oscilogram and (8) audioespectrogram of call type A. (9) Oscilogram and (10) audioespectrogram of call type B. Specimen recorded at Praia do Peró, Municipality of Cabo Frio, Rio de Janeiro, Brazil, on January 10th, 2013 (MNRJ 84347). After recordings, air temperature was registered at $23.4^{\circ} \mathrm{C}$ and relative air humidity at $89 \%$. Analyses were conducted using the following parameters: window function Hann, amplitude logarithmic, window size 256 samples and overlap 99\%.

\section{DISCUSSION}

We did not observe a significant difference in call type A (advertisement calls) among our study populations, because all analyzed parameters are congruent within populations. Population 3 (Praia do Forno) exhibited few differences when compared with populations 1 (Pedra de Itacoatiara) and 2 (Praia do Peró), except for their lower number of notes per call and number of pulses per notes (Table I). However, calls showed a very similar structure with any quantitative differences falling within the range of variation of the species. Most likely, it was caused by the lower number of calls analyzed for population 3 (Praia do Forno), or the social context of the recording. The interval between calls was the most variable parameter among populations. We observed that when males are calling alone, or with few active males, the interval between calls tends to be longer than when a large number of calling males are present, in which case the intervals between calls become shorter.

Our analysis suggests that call type B (aggressive/territorial) shows little variation among populations. Structurally, all calls analyzed have a similar pattern, which varied mainly in the number of emitted notes and interval between notes. Based on the observed social context of recorded males, we hypothesized that resident calling males might increase the number of notes of call type B in the presence of a higher abundance of active males in the vicinity (i.e. nearest five meters approximately). To further reinforce this hypothesis, the frequency of emission of type B calls or a combination of type $A+B$ calls also increased under this condition. Additionally, we observed antiphonic interactions (sensu Wells 2007) thus, corroborating the behavior reported by Alves-SiLva $\&$ SILVA (2009). Pairs of calling males approximately 1-2 m apart emitted calls type B or combined A + B in an alternated 
sequence without overlapping. The interactions lasted around 1-2 minutes.

Below, we examine the advertisement (or type A here) and territorial/aggressive (or type B here) calls of Scinax perpusillus group comparing the main variables described among them (see Table I). However, unbalanced approaches and the different methods used by authors in the description of vocal repertories of species belonging to the $S$. perpusillus group may hinder our comparisons (see legend in Table I).

The analysis of advertisement calls of S. littoreus does not suggest that frequencies are structured in harmonic bands, which can be shared with other described advertisement calls for the group (e.g., S. arduous, S. belloni, and S. perpusilus). The numbers of pulses per note found in the advertisement calls of $S$. littoreus are consistent with the numbers reported for S. arduous, S. peixotoi, and S. perpusillus. Notwithstanding, the duration of the call of $S$. littoreus is similar to that of $S$. arduous and $S$. peixotoi. Additionally, the numbers of notes per call seem more like the pattern observed for $S$. arduous, $S$. belloni, S. peixotoi, and S. perpusillus. All species belonging to this group present a similar interval between notes, except for $S$. peixotoi, which exhibits an interval between notes longer than the entire advertisement call (BRAsILEIro et al. 2007) and, presumably, the authors referred to the interval between calls. Finally, the dominant frequency spectrum reached by $S$. littoreus resembles those of $S$. insperatus and $S$. perpusillus. Therefore, our results indicate that the advertisement call of $S$. littoreus, in turn, resembles the calls described for $S$. arduous, S. peixotoi, and S. perpusillus, which includes numbers of notes per call, numbers of pulses per note, and call duration. Moreover, the advertisement call of $S$. cosenzai was the most divergent, considering the same aforementioned variables (for references and comparisons, see Table I).

Regarding territorial calls, our comparisons are limited, since this type of call had been previously described for only two species of the group: Scinax arduous and S. perpusillus (Pombal \& Bastos 2003). We compared our data on territorial (or aggressive) call and concluded that duration of territorial calls of $S$. littoreus is intermediate between $S$. arduous and $S$. perpusillus. Observing the number of notes per call, $S$. arduous and $S$. perpusillus emitted fewer notes than $S$. littoreus. The number of pulses per note is more similar to $S$. perpusillus, while $S$. arduous emitted a greater number of pulses. Finally, regarding frequencies, the frequency band of $S$. arduous and $S$. perpusillus was lower than the frequency band of $S$. littoreus (for references and comparisons, see Table II).

The use of behavioral traits in phylogenies has increased, and the usefulness of acoustic characters has been emphasized by many authors in the last two decades (e.g., DE Queiroz \& Wemberger 1993, Goicochea et al. 2010). In general, advertisement calls of species belonging to the $S$. perpusillus group have a multipulsed structure (HEYER et al. 1990, BRASILEIRO et al. 2007, Pombal \& Bastos 2003, Peres \& Simon 2011, Lacerda et al. 2012, Silva \& Alves-Silva 2011, this study). However, according to Pombal et al. (1995b), the multipulsed structure is a widespread condition in all species of Scinax and therefore could be uninformative within the genus in a phylogenetic context.

Even though other types of calls (e.g., territorial/aggressive) may not be suitable for sexual recognition, they may be an important character for phylogenetic purposes (Pombal \& Bastos 2003). Furthermore, Pombal \& Bastos (2003) affirmed that the territorial call of Scinax catharinae group is multipulsed, as in the $S$. perpusillus species group, and remarkably different from the $S$. ruber species group, which is shorter, modulated, and has a harmonic structure (Pombal 1995a). This is in accordance with the suggestion of FaIvovich et al. (2002) that the $S$. perpusillus species group is the sister clade to the $S$. catharinae group. For the reasons explained above, we suggest that descriptions contained in this work must be considered in future studies dealing with phylogenetics of the genus Scinax. Also, we strongly encourage future studies of $S$. perpusillus group to describe in detail the territorial/aggressive calls as well as standardize descriptions in order to favor future comparisons.

\section{Geographic distribution and conservation remarks}

During the past few decades, restinga and coastal environments have been extensively deforested due to sprawl (Rocha et al. 2007), which may be impacting Scinax littoreus because this species seems to be restricted to this type of habitat. Nevertheless, Peixoto \& Carvalho-e-Silva (2004) pointed out that this species is categorized as "least concern" (LC) according to the IUCN criteria. Despite the occurrence of this species in a few protected areas (Parque Estadual da Serra da Tiririca - Alves-Silva \& Silva 2009; Núcleo Experimental Iguaba Grande - Martins et al. 2012; Parque Estadual da Costa do Sol -unpublished data), the specificity of habitat choice by this species (tank-bromeliads) and the recent increase of infrastructure developments in its area of occurrence suggests that a more careful evaluation of its conservation status is warranted.

\section{ACKNOWLEDGMENTS}

We are grateful to J.P. Pombal Jr and Ulisses Caramaschi (MNRJ) for allowing us to study preserved specimens under their care; to Fabio Hepp for valuable suggestions in the earlier versions of this manuscript: W. Bryan Jennings (MNRJ) for English review. RP thanks Conselho Nacional do Desenvolvimento Científico e Tecnológico (CNPq) for his scholarship. DB thanks Fundação de Amparo a Pesquisa do Estado de São Paulo (FAPESP), CM and DB acknowledge Coordenação de Aperfeiçoamento Pessoal de Nível Superior (CAPES) for their scholarships. We also grateful to Fundação do Amparo à Pesquisa do Estado do Rio de Janeiro (FAPERJ), CNPq and CAPES for the equipment support to UFRJ, MN. 
Table I. Comparative table of known advertisement calls of Scinax perpusillus group. Data are given as minimum-maximum.

\begin{tabular}{|c|c|c|c|c|c|c|}
\hline Species & $\begin{array}{l}\text { Call duration } \\
(s)\end{array}$ & $\begin{array}{l}\text { Call interval } \\
(s)\end{array}$ & Number of notes & $\begin{array}{l}\text { Note duration } \\
(\mathrm{s})\end{array}$ & $\begin{array}{l}\text { Note interval } \\
(s)\end{array}$ & $\begin{array}{l}\text { Number of } \\
\text { pulses/note }\end{array}$ \\
\hline S. alcatraz & - & - & - & - & - & - \\
\hline S. arduous & $0.198-0.328$ & $0.234-0.283$ & $4-6$ & $0.014-0.045$ & $0.023-0.051$ & $5-13$ \\
\hline S. atratus & - & - & - & - & - & - \\
\hline S. belloni ${ }^{\mathrm{c}-2}$ & $0.59-0.690$ & $1.410-3.960$ & 2 & $0.017-0.021$ & $0.028-0.036$ & $28-35$ \\
\hline S. belloni ${ }^{\mathrm{c}-3}$ & $0.100-0.120$ & $1.410-3.960$ & 3 & $0.016-0.024$ & $0.027-0.036$ & $24-31$ \\
\hline S. cosenzai & $0.177-2.066$ & $1.9-4.32$ & $2-14$ & $0.0018-0.111$ & $0.010-0.516$ & $1-33$ \\
\hline S. faivovichi & - & - & - & - & - & - \\
\hline S. insperatus ${ }^{1}$ & - & - & $25-50^{\mathrm{a}}$ & - & $0.630-0.860$ & $155-434^{b}$ \\
\hline S. insperatus ${ }^{2}$ & - & - & $23-47^{a}$ & - & $0.050-0.631$ & $223-500^{b}$ \\
\hline S. littoreus ${ }^{1}$ & $0.204-0.282$ & $1.009-7.027$ & $2-4$ & $0.118-0.291$ & $0.024-0.038$ & $2-8$ \\
\hline S. littoreus ${ }^{2}$ & $0.174-0.287$ & $0.980-2.781$ & $2-9$ & $0.255-0.348$ & $0.026-0.029$ & $3-9$ \\
\hline S. littoreus ${ }^{3}$ & $0.201-0.223$ & 2.122-14.197 & $3-4$ & $0.230-0.371$ & $0.025-0.027$ & $2-4$ \\
\hline S. melloi & - & - & - & - & - & - \\
\hline S. perpusillus & $0.092-0.174$ & $0.776-1.067$ & $3-6$ & $0.007-0.018$ & 0.009-0.059 & $3-5$ \\
\hline S. perpusillus* & $0.250-0.400$ & - & $4-5$ & $0.03-0.07$ & - & $4-10$ \\
\hline S. peixotoi & $0.146-0.232$ & $0.438-2.400$ & $3-5$ & $0.009-0.028$ & $0.438-2.400$ & $4-9$ \\
\hline S tupinamba & - & - & - & - & - & - \\
\hline S. v-signatus & - & - & - & - & - & - \\
\hline & $\begin{array}{c}\text { Pulses duration } \\
\text { (s) }\end{array}$ & $\begin{array}{c}\text { Dominant } \\
\text { Frequency }(\mathrm{kHz})\end{array}$ & $\begin{array}{c}\text { Low Frequency } \\
(\mathrm{kHz})\end{array}$ & $\begin{array}{c}\text { High Frequency } \\
(\mathrm{kHz})\end{array}$ & \multicolumn{2}{|l|}{ Reference } \\
\hline S. alcatraz & - & - & - & - & \multicolumn{2}{|l|}{ Unknown } \\
\hline S. arduous & $0.002-0.004$ & $3802-4682$ & - & - & \multicolumn{2}{|c|}{ Pombal \& Bastos (2003) } \\
\hline S. atratus & - & - & - & - & \multicolumn{2}{|l|}{ Unknown } \\
\hline S. belloni ${ }^{\mathrm{c}-2}$ & - & 3078 & 1723 & 5275 & \multicolumn{2}{|c|}{ Perez \& Simon (2011) } \\
\hline S. belloni ${ }^{\mathrm{c}-3}$ & - & 3078 & 1723 & 5275 & \multicolumn{2}{|c|}{ Perez \& Simon (2011) } \\
\hline S. cosenzai & - & $3375-4571$ & - & - & \multicolumn{2}{|c|}{ LACERDA et al. (2012) } \\
\hline S. faivovichi & - & - & - & - & \multicolumn{2}{|l|}{ Unknown } \\
\hline S. insperatus ${ }^{1}$ & - & $4479-4665^{c}$ & - & - & \multicolumn{2}{|c|}{ SILVA \& ALVES-SILVA (2011) } \\
\hline S. insperatus ${ }^{2}$ & - & $4479-4665^{c}$ & - & - & \multicolumn{2}{|c|}{ SILVA \& AlvES-SILVA (2011) } \\
\hline S. littoreus ${ }^{1}$ & $0.004-0.015^{c}$ & $4306.6-4478.9$ & $2261.2-2756.2$ & $5892.7-6653.0$ & \multicolumn{2}{|l|}{ This study } \\
\hline S. littoreus ${ }^{2}$ & $0.009-0.024^{c}$ & $4512.7-4651.2$ & $2281.0-2450.0$ & $6431.2-8122.3$ & \multicolumn{2}{|l|}{ This study } \\
\hline S. littoreus ${ }^{3}$ & $0.007-0.011^{c}$ & 4306.6 & 2471.1 & 6272.8 & \multicolumn{2}{|l|}{ This study } \\
\hline S. melloi & - & - & - & - & \multicolumn{2}{|l|}{ Unknown } \\
\hline S. perpusillus & $0.002-0.005$ & $4554-4856$ & - & - & \multicolumn{2}{|c|}{ Pombal \& Bastos (2003) } \\
\hline S. perpusillus* & - & $3500-5900$ & 2900 & 7000 & \multicolumn{2}{|c|}{ HEYER et al. (1990) } \\
\hline S. peixotoi & $0.001-0.003$ & $3617-3963$ & - & - & \multicolumn{2}{|c|}{ BrasileIRo et al. (2007) } \\
\hline S tupinamba & - & - & - & - & \multicolumn{2}{|l|}{ Unknown } \\
\hline S. v-signatus & - & - & - & - & \multicolumn{2}{|l|}{ Unknown } \\
\hline
\end{tabular}

Scinax belloni ${ }^{\mathrm{c}-2^{*}}$ : advertisement call with two notes; S. belloni ${ }^{\mathrm{c}-3}$ : advertisement call with three notes; $S$. insperatus ${ }^{1}$ : male one to duets of antiphonic interaction; $S$. insperatus ${ }^{2}$ : male two to duets of antiphonic interaction; $S$. littoreus ${ }^{1}$ : population 1 from Pedra de Itacoatiara; S. littoreus ${ }^{2}$ : population 2 from Praia do Peró; S. littoreus ${ }^{3}$ : population 3 from Praia Forno; ${ }^{a}$ : SILVA \& Alves-SILVA (2011) considered this interval as number of notes while other authors considered this interval as call series; ${ }^{b}$ : this interval probably corresponds to the total number of pulses emitted by each specimen, probably SILVA \& ALVES-SILVA (2011) refers as a pulse, other authors refers as notes (see discussion in LACERDA et al. 2012); c: this variable corresponds to the interval between peaks of notes; *: HeYer et al. (1990) and POMBAL \& BASTOS (2003) signaled that $S$. perpusillus from Boracéia could consist in a divergent species. 
Table II. Comparative table of known aggressive/territorial calls Scinax perpusillus group. Data are given as minimum-maximum.

\begin{tabular}{|c|c|c|c|c|c|c|}
\hline Species & $\begin{array}{c}\text { Call duration } \\
(\mathrm{s})\end{array}$ & $\begin{array}{l}\text { Call interval } \\
(s)\end{array}$ & $\begin{array}{c}\text { Number of } \\
\text { notes }\end{array}$ & $\begin{array}{l}\text { Note duration } \\
(\mathrm{s})\end{array}$ & $\begin{array}{l}\text { Note interval } \\
(\mathrm{s})\end{array}$ & $\begin{array}{l}\text { Number of } \\
\text { pulses/note }\end{array}$ \\
\hline S. arduous & $0.053-0.064$ & $0.082-0.116$ & 1 & $0.053-0.064$ & $0.082-0.116$ & $18-22$ \\
\hline S. littoreus ${ }^{1}$ & $0.267-0.322$ & $0.981-1590$ & $14-22$ & $0.020-0.049$ & $0.009-0.0018^{a}$ & $2-4$ \\
\hline S. littoreus ${ }^{2}$ & $0.274-0.349$ & $0.689-0.915$ & $16-31$ & $0.016-0.034$ & $0.012-0.027^{a}$ & $2-4$ \\
\hline S. littoreus ${ }^{3}$ & $0.220-0.298$ & $1.228-1.374$ & $8-12$ & $0.022-0.058$ & $0.003-0.023^{a}$ & $2-4$ \\
\hline S. perpusillus & $0.314-0.400$ & $0.748-0.792$ & $6-12$ & $0.008-0.042$ & $0.008-0.064$ & $1-6$ \\
\hline & $\begin{array}{c}\text { Pulses duration } \\
(\mathrm{s})\end{array}$ & $\begin{array}{c}\text { Dominant Frequency } \\
(\mathrm{kHz})\end{array}$ & $\begin{array}{l}\text { Low Frequency } \\
(\mathrm{kHz})\end{array}$ & $\begin{array}{l}\text { High Frequency } \\
(\mathrm{kHz})\end{array}$ & \multicolumn{2}{|c|}{ Reference } \\
\hline S. arduous & $0.002-0.004$ & $3760-4445$ & - & - & \multicolumn{2}{|c|}{ Pombal \& BAStos (2003) } \\
\hline S. littoreus ${ }^{1}$ & $0.001-0.004 b$ & $5304.6-5439.0$ & $2152.0-2846.0$ & $5292.0-5839.0$ & \multicolumn{2}{|l|}{ This study } \\
\hline S. littoreus ${ }^{2}$ & $0.002-0.004 b$ & $5356.2-5439.0$ & $2352.8-2765.6$ & $5292.8-5434.6$ & \multicolumn{2}{|l|}{ This study } \\
\hline S. littoreus ${ }^{3}$ & $0.002-0.004 b$ & 5292.0 & 2284.0 & 5498.0 & \multicolumn{2}{|l|}{ This study } \\
\hline S. perpusillus & 0.004-0.009 & $4902-4918$ & - & - & \multicolumn{2}{|c|}{ POMBAL \& BASTOS (2003) } \\
\hline
\end{tabular}

Scinax littoreus ${ }^{1}$ : population 1 from Pedra de Itacoatiara; S. littoreus ${ }^{2}$ : population 3 from Praia Forno; S. littoreus ${ }^{3}$ : population 2 from Praia do Peró; ${ }^{a}$ : this interval corresponds to the beginning of aggressive call (see call description for more details); ${ }^{\text {b: }}$ this variable corresponds to the interval between peaks of notes.

\section{LITERATURE CITED}

Alves-Silva, R. \& H.R. SiLva. 2009. Life in bromeliads: reproductive behaviour and the monophyly of the Scinax perpusillus species group (Anura: Hylidae). Journal of Natural History 43 (3-4): 205-207.

Brasileiro, C.A.; C.F. Haddad; R.J. Sawaya \& M. Martins. 2007. A new and threatened species of Scinax (Anura; Hylidae) from Queimada Grande Island, Southeastern Brazil. Zootaxa 1391: 47-55.

Canedo, C. \& J.P. Pombal JR. 2007. Two new species of torrent frog of the genus Hylodes (Anura, Hylodidae) with nuptial thumb tubercles. Herpetologica 63: 224-235.

de Queiroz, A. \& P.H. Wimberger. 1993. The uselfuness of behavior for phylogeny estimation: levels of homoplasy in behavioral and morphological characters. Evolution 47 (1): 46-60.

Duellman, W.E. \& L. Trueb. 1994. Biology of amphibians. London, McGraw-Hill, $2^{\text {nd }}$ ed., 670p.

Farvovich, J. 2002. A cladistic analysis of Scinax (Anura: Hylidae). Cladistic 18 (4): 367-393.

Frost, D.R. 2013. Amphibian Species of the World: an Online Reference. Version 5.5, available on line at http://research. amnh.org/vz/herpetology/amphibia [Acessed: 31/I/2013]

Goicochea, N.; I. De La Riva \& J.M. Padial. 2010. Recovering phylogenetic signal from frog mating calls. Zoologica Scripta 39: 141-154.

Heyer, W.R.; A.S. Rand; C.A.G. Cruz; O.L. Peixoto \& C.E. Nelson. 1990. Frogs of Boracéia. Arquivos de Zoologia 31 (4): 231-410.

Lacerda, J.V.A.; O.L. Peixoto \& R.N. Feio. 2012. A new species of the bromeligenous Scinax perpusillus group (Anura; Hylidae) from Serra do Brigadeiro, State of Minas Gerais, southeastern Brazil. Zootaxa 3271: 31-42.

Martins, A.R.; S.F. Bruno \& A.Q. Navegantes. 2012. Herpetofauna of Núcleo Experimental de Iguaba Grande, Rio de Janeiro state, Brazil. Brazilian Journal of Biology 72 (3): 553-562.

Peixoto, O.L. 1988. Sobre o "status" taxonômico de Hyla catharinae alcatraz B. Lutz 1973, com a descricão de uma nova espécie para o grupo "perpusilla" (Amphibia, Anura, Hylidae). Acta BiologicaLeopoldensia 10 (2): 253-267.

Peixoto, O.L. \& Carvalho-e-Silva. 2004. Scinax littoreus. In: IUCN 2013. IUCN Red List of Threatened Species. Version 2013.1, available on line at http://www.iucnredlist.org [Acessed: 31/ I/2013].

Peres, J. \& J.E Simon. 2011. O canto de anúncio de Scinax belloni Faivovich, Gasparini \& Haddad, 2010 (Amphibia: Anura: Hylidae). Revista Científica Faesa 7: 47-54.

Pombal JR, J.P.; C.F.B. Haddad \& S. Kasahara. 1995a. New species of Scinax (Anura: Hylidae) from southeastern Brazil, with comments on the genus. Journal of Herpetology 29 (1): 1-6.

Pombal JR, J.P. \& R.P. BAStos. 2003. Vocalizações de Scinax perpusillus (A. Lutz \& B. Lutz, 1939) e S. arduous Peixoto, 2002 (Anura, Hylidae), com comentários taxonômicos. Revista Brasileira de Zoologia 20 (4): 607-610.

Pombal JR, J.P.; R.P. Bastos \& C.F.B. Haddad. 1995b. Vocalizações de algumas espécies do gênero Scinax (Anura, Hylidae) do sudeste do Brasil e comentários taxonômicos. Naturalia 20: 213-225.

Pombal Jr, J.P.; M. Bilate; P.G. Gambale; L. Signorelli \& R.P. BasTos. 2011. A new miniature treefrog of the Scinax ruber clade from the Cerrado of Central Brazil (Anura: Hylidae). Herpetologica 67 (3): 288-299.

Rocha, C. F. D.; H.G. Bergallo; M. van Sluys; M.A.S. Alves \& C.E. 
JAMEL. 2007. The remnants of resting habitats in the Brazilian Atlantic Forest of Rio de Janeiro state, Brazil: Habitat loss and risk of disappearance. Brazilian Journal of Biology 67 (2): 263-273.

Silva, H.R. \& R. Alves-Silva. 2011. A new bromeligenous species of the Scinax perpusillus group from the hills of the State of Rio de Janeiro, Brazil (Anura, Hylidae). Zootaxa 3043: 54-68.
Taucce, P.P.G.; F.S.F. Leite; P.S. Santos; R.N. Feio \& P.C.A. Garcia. 2012. The advertisement call, color patterns and distribution extension of Ischnocnema izecksohni (Caramaschi and Kisteumacher, 1989) (Anura, Brachycephalidae). Papéis Avulsos de Zoologia 52: 111-119.

WeLls, K.D. 2007. The ecology and behavior of amphibians. Chicago, University of Chicago Press, 723p.

Submitted: 18.II.2013; Accepted: 13.V.2013.

Editorial responsibility: Kleber Del Claro 